\title{
Selective Synaptic Distribution of Kainate Receptor Subunits in the Two Plexiform Layers of the Rat Retina
}

\author{
Johann Helmut Brandstätter, Peter Koulen, and Heinz Wässle \\ Max-Planck-Institut für Hirnforschung, Abteilung für Neuroanatomie, D-60528 Frankfurt am Main, Germany
}

The synaptic localization of the kainate receptor subunits GluR6/7 and KA2 and of the ionotropic glutamate receptor subunits $\delta 1 / 2$ was studied in the rat retina using receptorspecific antisera. GluR6/7 and KA2 were present in both synaptic layers of the retina: the inner plexiform layer (IPL) and the outer plexiform layer (OPL). The localization of $\delta 1 / 2$ was restricted to the IPL. Detailed ultrastructural examination showed that in the OPL GluR6/7 was localized in horizontal cell processes postsynaptic to both rod spherules and cone pedicles. It was always only one of the two invaginating horizontal cell processes at the photoreceptor synapses labeled for GluR6/7. $\mathrm{KA} 2$ in the OPL was found only postsynaptic to cone pedicles and never postsynaptic to rod spherules. The KA2-labeled processes made flat contacts with the cone pedicles, suggesting they are the dendrites of OFF bipolar cells. In the IPL the different receptor subunits were localized postsynaptically to ribbon synapses of both rod and cone bipolar cells. As a rule, only one of the two postsynaptic elements at the bipolar cell dyad was stained for each of the receptor subunits examined. The selective and heterogeneous distribution of these receptors at the ribbon synapses of the OPL and IPL suggests a high degree of differential processing of the glutamatergic signals.

Key words: GluR6/7; KA2; $\delta 1 / 2$; kainate receptor subunits; horizontal cells; OFF bipolar cells; ON bipolar cells; amacrine cells; ganglion cells; outer plexiform layer; inner plexiform layer; immunocytochemistry
In the mammalian retina, glutamate mediates the synaptic transfer from the photoreceptors to bipolar and horizontal cells in the outer plexiform layer (OPL) and from bipolar to amacrine and ganglion cells in the inner plexiform layer (IPL) (for review, see Massey, 1990).

Glutamate acts on ionotropic and metabotropic receptors. Metabotropic glutamate receptors (mGluRs) are G-proteincoupled monomeric proteins that influence intracellular second messenger systems (for review, see Pin and Duvoisin, 1995). Several immunocytochemical studies have shown the localization of mGluRs in the mammalian retina (Nomura et al., 1994; Peng et al., 1995; Brandstätter et al., 1996; Koulen et al., 1996, 1997).

Ionotropic GluRs (iGluRs) form ligand-gated cation channels and mediate fast excitatory synaptic transmission. They are classified into AMPA, kainate, and NMDA receptors on the basis of pharmacological and electrophysiological characteristics (for review, see Monaghan et al., 1989; Seeburg, 1993; Hollmann and Heinemann, 1994). Recently, two receptor subunits termed $\delta 1$ and $\delta 2$ were identified. They are structurally related to iGluRs, but they constitute a separate protein subfamily (Yamazaki et al., 1992; Araki et al., 1993; Lomeli et al., 1993; Mayat et al., 1995).

Most of what we know about the localization of iGluRs in the mammalian retina originates from in situ hybridization studies at the mRNA level, and little is known about their protein localization (mRNA: Hughes et al., 1992; Müller et al., 1992; Hamassaki-

\footnotetext{
Received June 23, 1997; revised Sept. 10, 1997; accepted Sept. 12, 1997.

This work was supported by a grant from the Deutsche Forschungsgemeinschaft (SFB 269/B4). We thank Dr. R. J. Wenthold for providing the antiserum against the $\delta 1 / 2$ subunits. We also thank A. Leihkauf, G.-S. Nam, W. Hofer, and F. Boij for excellent technical assistance, and Dr. A. Hirano for reading and improving this manuscript.

Correspondence should be addressed to Johann H. Brandstätter, Max-PlanckInstitut für Hirnforschung, Abteilung für Neuroanatomie, Deutschordenstrasse 46, D-60528 Frankfurt am Main, Germany.

Copyright (C) 1997 Society for Neuroscience $0270-6474 / 97 / 179298-10 \$ 05.00 / 0$
}

Britto et al., 1993; Brandstätter et al., 1994; Zhang et al., 1996; protein: Hartveit et al., 1994; Peng et al., 1995; Qin and Pourcho, 1996; Hughes, 1997).

Photoreceptors are hyperpolarized by light and release glutamate in darkness. Horizontal cells and OFF bipolar cells are hyperpolarized by a light stimulus, whereas $\mathrm{ON}$ bipolar cells are depolarized. Different types of GluRs generate this dichotomy: iGluRs (sign conserving) are expressed by horizontal cells and OFF bipolar cells, and mGluRs (sign inverting) are expressed by ON bipolar cells (for review, see Djamgoz et al., 1995; Shiells, 1995).

Several studies have shown the identity of the sign-inverting mGluR. It is mGluR6, a receptor most potently activated by the glutamate agonist L-AP4, which on binding of glutamate hyperpolarizes ON bipolar cells (Yamashita and Wässle, 1991; Nakajima et al., 1993; Nomura et al., 1994; de la Villa et al., 1995; Masu et al., 1995; Euler et al., 1996).

Only circumstantial evidence is available concerning the types of AMPA and kainate receptors present at the sign-conserving OFF bipolar cell synapse (Peng et al., 1995; Qin and Pourcho, 1996). It is difficult to record pure kainate responses because kainate also activates AMPA receptors, giving rise to nondesensitizing responses (Lerma et al., 1997). Therefore, knowledge of the distribution of kainate receptors is important for understanding their role in glutamatergic synaptic transmission.

In the present study, we applied specific antisera against the kainate receptor subunits GluR6/7 and KA2 and against the iGluRs $\delta 1 / 2$ to sections of the rat retina. The distributions of the receptor subunits were studied by light microscopy, and their synaptic localizations were investigated by electron microscopy. The results show an unexpected specificity of the distribution of the receptor subunits at the ribbon synapses both in the OPL and the IPL, suggesting a high degree of differential processing of the glutamatergic signals. 


\section{MATERIALS AND METHODS}

Antisera against GluR6/7, KA2, and $\delta 1 / 2$. The affinity-purified, polyclonal antisera against GluR6/7 and KA2 were obtained from Upstate Biotechnology (Lake Placid, NY). They were generated in rabbit against a C-terminal peptide of rat GluR6 (KHTFNDRRLPGKETMH) and of rat KA2 (KTSPPRPRPGPTGPRELTEHE). The affinity-purified, polyclonal antiserum against $\delta 1 / 2$ was a generous gift of Dr. R. J. Wenthold (National Institutes of Health, Bethesda, MD). It was raised in rabbit against a C-terminal peptide of rat $\delta 2$ (Mayat et al., 1995).

Animals and tissue preparation. Retinae of adult albino rats, 6- to 8 -weeks old, were investigated. The rats were anesthetized deeply with halothane and decapitated. For light microscopy, the eyes were opened along the ora serrata, and the eyecups were immersion-fixed for 15 to 30 min in $4 \%(\mathrm{w} / \mathrm{v})$ paraformaldehyde in phosphate buffer $(\mathrm{PB})(0.1 \mathrm{M}, \mathrm{pH}$ 7.4). The vitreous body was removed, and the retinae were dissected free. The retinae were cryoprotected in $10 \%(\mathrm{w} / \mathrm{v})$ and $20 \%(\mathrm{w} / \mathrm{v})$ sucrose in $\mathrm{PB}$ for $1 \mathrm{hr}$ each and in $30 \%$ (w/v) sucrose in PB overnight at $4^{\circ} \mathrm{C}$. Pieces of retinae were mounted in freezing medium (Reichert-Jung, Bensheim, Germany), sectioned vertically at $12 \mu \mathrm{m}$ thickness on a cryostat, and collected on gelatin-coated slides.

For electron microscopy a compromise had to be made between the preservation of the tissue and the protection of the antigenicity (Grünert and Wässle, 1993; Hartveit et al., 1994; Sassoè-Pognetto et al., 1994; Greferath et al., 1995; Brandstätter et al., 1996; Enz et al., 1996). The antisera used were very fixation-sensitive, and given the need to maximize immunoreactivity, the tissue received only minimal fixation. The eyecups were fixed in $4 \%(\mathrm{w} / \mathrm{v})$ paraformaldehyde and $0.01 \%(\mathrm{v} / \mathrm{v})$ glutaraldehyde in PB for $10 \mathrm{~min}$, followed by an additional $40 \mathrm{~min}$ in $4 \%$ $(\mathrm{w} / \mathrm{v})$ paraformaldehyde in PB. After the retinae were dissected out and cryoprotected, they were frozen and thawed repeatedly to enhance the penetration of the antisera. After the retinae were washed in PBS (0.01 $\mathrm{M}, \mathrm{pH} 7.4)$, small pieces of retina were embedded in agar, and vertical sections (50 $\mu \mathrm{m}$ thick) were cut with a vibratome for pre-embedding electron microscopic immunocytochemistry.

Light microscopic immunocytochemistry. The antisera were used at a concentration of $0.2 \mu \mathrm{g} / \mathrm{ml}$ (anti-GluR6/7), $1.8 \mu \mathrm{g} / \mathrm{ml}$ (anti-KA2), and 1 $\mu \mathrm{g} / \mathrm{ml}$ (anti- $\delta 1 / 2)$. Immunocytochemical labeling was performed using the indirect fluorescence method. The binding sites of the primary antisera were revealed by the secondary antiserum goat anti-rabbit IgG coupled to carboxymethylindocyanine ( $\mathrm{Cy} 3$, red fluorescence; Dianova, Hamburg, Germany) diluted 1:1000.

Pre-embedding immunoelectron microscopy. The vibratome sections were collected in cold PBS, immersed for blocking for $2 \mathrm{hr}$ in $10 \%$ NGS $(\mathrm{v} / \mathrm{v})$ in $\mathrm{PBS}$, and then incubated in the primary antisera against GluR6/7, KA2, and $\delta 1 / 2$. The primary antisera were used at the same concentration and diluted in the same medium, but without Triton $\mathrm{X}-100$, as used for light microscopy. The vibratome sections were incubated in the primary antisera for $4 \mathrm{~d}$ at $4^{\circ} \mathrm{C}$. Thereafter, the sections were rinsed in PBS several times and incubated for $2 \mathrm{hr}$ at room temperature in biotinylated goat anti-rabbit IgG (1:100; SigmaAldrich, Deisenhofen, Germany). After the sections were rinsed again in PBS, they were transferred to a solution containing the extravidinperoxidase complex (1:100; Sigma-Aldrich) for $2 \mathrm{hr}$ at room temperature. After washes in PBS and in $0.05 \mathrm{M}$ Tris- $\mathrm{HCl}$, pH 7.6, the sections were preincubated for $10 \mathrm{~min}$ in $3,3^{\prime}$-diaminobenzidine (DAB) [0.05\% (v/v) in $0.05 \mathrm{M}$ Tris-HCl, pH 7.6], and then reacted in $0.05 \%(\mathrm{v} / \mathrm{v}) \mathrm{DAB}$ with $0.01 \%(\mathrm{v} / \mathrm{v}) \mathrm{H}_{2} \mathrm{O}_{2}$. The staining reaction was stopped by rinsing the sections in Tris-HCl. Subsequently, the sections were rinsed in 0.1 $\mathrm{M}$ cacodylate buffer, $\mathrm{pH} 7.4$, post-fixed in $2.5 \%(\mathrm{v} / \mathrm{v})$ glutaraldehyde in cacodylate buffer $\left(2 \mathrm{hr}\right.$ at $\left.4^{\circ} \mathrm{C}\right)$, and washed in cacodylate buffer overnight at $4^{\circ} \mathrm{C}$. The DAB reaction product was silver-intensified and treated with $0.05 \%(\mathrm{w} / \mathrm{v})$ gold chloride (Sigma), using a modified version of a procedure described previously (Leranth and Pickel, 1989). The sections were then post-fixed with $2 \%(\mathrm{w} / \mathrm{v}) \mathrm{OsO}_{4}$ in cacodylate buffer for $1 \mathrm{hr}$, dehydrated in a graded series of ethanol (30-100\%) followed by propyleneoxide, and flat-embedded in Epon 812 (Serva, Heidelberg, Germany). Ultrathin sections were cut and then stained with uranyl acetate and lead citrate. Control vibratome sections were processed as described above, except that the first antisera were omitted. These produced no staining.

Ultrathin sections were examined and photographed with a Zeiss EM10 electron microscope.

Characterization of the antisera against GluR6/7 and KA2. The antiserum against $\delta 1 / 2$ has been fully characterized and used previously for light and electron microscopic distribution studies (Mayat et al., 1995).

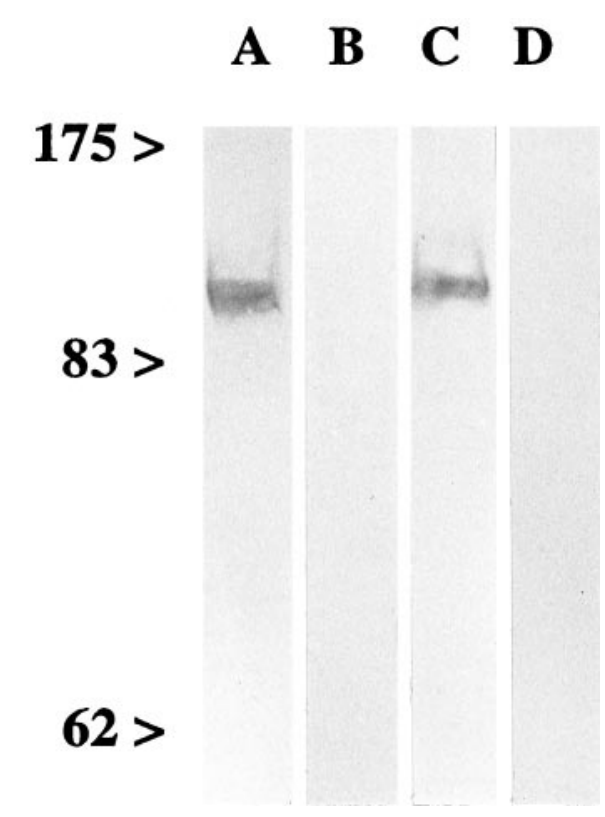

Figure 1. Specificity of the antisera against GluR6/7 and KA2. Membrane proteins of rat retina $(80 \mu \mathrm{g} /$ lane $)$ were separated on a $7.5 \%$ SDS-PAGE gel and transferred onto nylon membrane. Numbers and arrowheads indicate the position and weight $(\mathrm{kDa})$ of the marker bands. $A$, $C$, The antiserum against GluR6/7 $(A)$ and KA2 $(C)$ labeled a protein band at $\sim 110$ and $120 \mathrm{kDa}$, respectively. $B, D$, Labeling was prevented by coincubation of the antiserum with the antigenic peptide, shown in $B$ for GluR6/7 and in $D$ for KA2.

The specificity of the antisera against GluR6/7 and KA2 was assessed by immunoblotting of rat retina membrane proteins (see Fig. 1). A detailed description of the procedure is given in Brandstätter et al. (1996). The binding of the antisera against GluR6/7 and KA2 to polypeptides was detected by goat anti-rabbit IgG antibodies coupled to HRP (diluted 1:100; Vector Laboratories, Burlingame, CA) using 4-chloro-1-naphthol (Sigma, St. Louis, MO) as substrate and an enzymatic detection system (Vectastain Elite ABC kit, Vector Laboratories).

The antisera against GluR6/7 and KA2 detected a single protein band with a molecular weight of $\sim 110 \mathrm{kDa}$ for GluR6/7 and $120 \mathrm{kDa}$ for KA2 in membrane preparations of rat retina (see Fig. 1A,C). This is in agreement with the molecular weight deduced from the cDNA sequence of GluR6 and GluR7 (Egebjerg et al., 1991; Bettler et al., 1992) and of KA2 (Herb et al., 1992; Sakimura et al., 1992). Preincubation of the antisera against GluR6/7 and KA2 with a 10 -fold excess (w/w) of the respective antigenic peptide lead to no labeling in the subsequent immunoblot analysis (Fig. $1 B, D$ ).

For staining of retina sections, controls were made by preincubating the antisera against GluR6/7 and KA2 with a 10-fold excess of their respective antigenic peptides for $1 \mathrm{hr}$ at room temperature, before applying to the retina sections, which resulted in a complete loss of specific staining (see Fig. 2B,D).

\section{RESULTS}

\section{Light microscopic distribution of GluR6/7, KA2, and $\delta 1 / 2$ in the rat retina}

In vertical sections of the adult rat retina, immunofluorescence for the different iGluR subunits showed characteristic patterns of labeling (Fig. 2). Staining for the three subunits was most prominent in the IPL, where it had a mixture of punctate and diffuse appearance. The puncta are most distinct in the case of the $\delta 1 / 2$ subunits (Fig. 2E), and they are less distinct in the micrographs showing the GluR6/7 subunits (Fig. $2 A$ ) and the KA2 subunit (Fig. $2 C$ ). Clouds of puncta fuse in the low-power micrographs of Figure $2 A, C$, but inspection at the microscope using a high-power objective resolves the punctate nature of the immunofluores- 

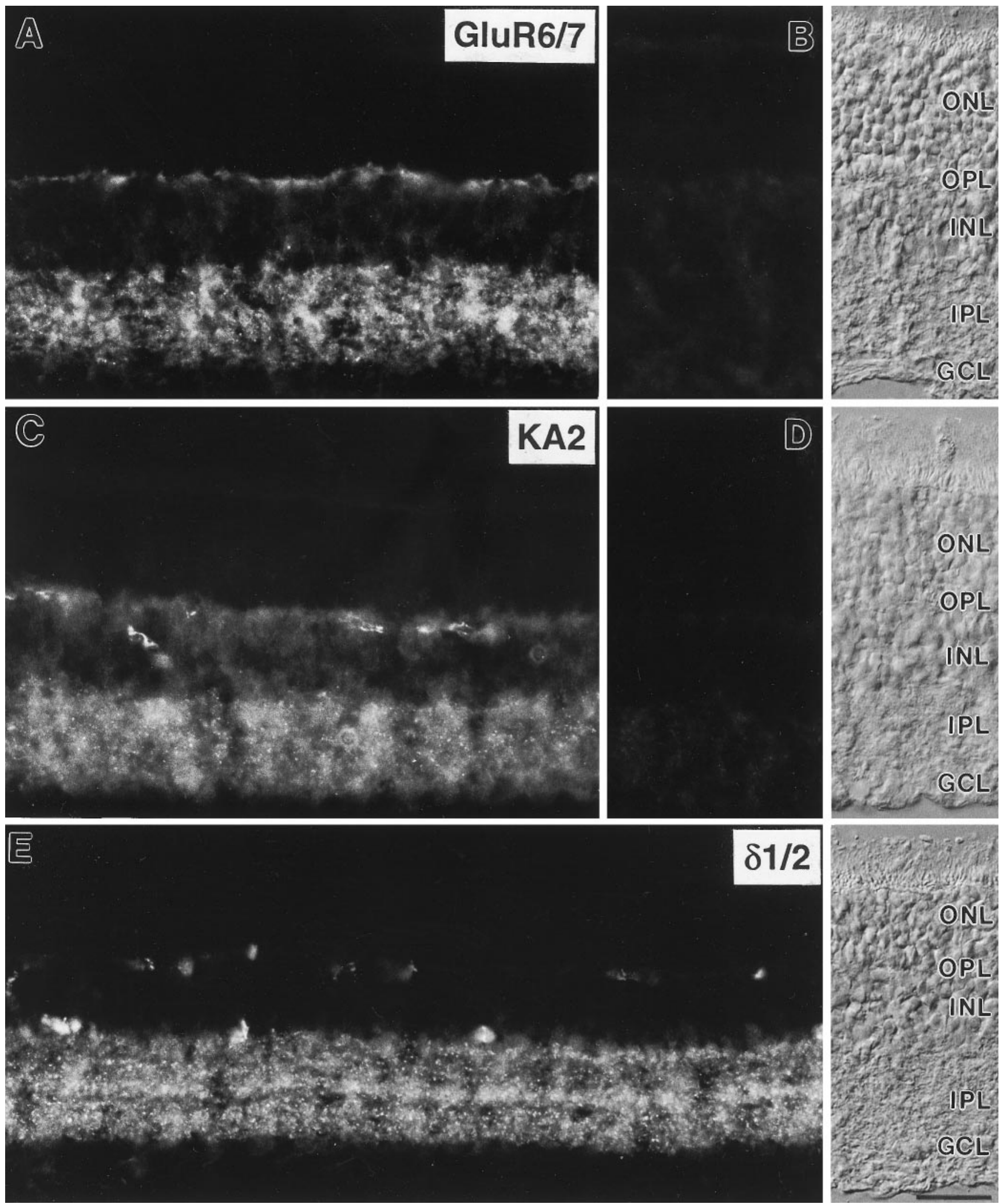

Figure 2. Micrographs of vertical cryostat sections of rat retina immunostained with the antisera against GluR6/7, KA2, and $\delta 1 / 2$. $A$, Diffuse and punctate labeling for GluR6/7 was present in both synaptic layers, the $O P L$ and the IPL. B, Preadsorption of the anti-GluR6/7 antiserum with the immunogen resulted in a complete loss of specific immunoreactivity. $C$, Diff use and punctate labeling for KA2 was also present in both plexiform layers of the rat retina. In addition, somata in the inner nuclear layer showed weak KA2 immunostaining. $D$, No specific immunolabel was detected after preadsorption of the anti-KA2 antiserum with the immunogen. E. Punctate labeling for $\delta 1 / 2$ was present in several distinct strata in the $I P L$. Stained profiles in the $O P L$ are unspecifically labeled blood vessels. The retinal layers are shown with Nomarski optics. $O N L$, Outer nuclear layer; $O P L$, outer plexiform layer; $I N L$, inner nuclear layer; $I P L$, inner plexiform layer; $G C L$, ganglion cell layer. Scale bar, $25 \mu \mathrm{m}$. 
cence. Comparable to our previous results on the retinal localization of glycine receptors, GABA receptors, and GluRs, this punctate staining pattern indicates a clustering of the iGluR subunits in synaptic "hot spots" (Grünert and Wässle, 1993; Hartveit et al., 1994; Sassoè-Pognetto et al., 1994; Greferath et al., 1995; Brandstätter et al., 1996; Enz et al., 1996).

Immunoreactivity was also found in the OPL for GluR6/7 (Fig. 2A) and KA2 (Fig. 2C). Only nonspecific staining of blood vessels can be detected in the OPL in the case of the $\delta 1 / 2$ subunits (Fig. 2E).

In addition to the label in the plexiform layers, diffuse immunofluorescence was also observed for GluR6/7 (Fig. 2A) and KA2 (Fig. $2 C$ ) on cell somata and processes in the inner nuclear layer. This suggests extrasynaptic localization of these iGluRs. In control experiments, preadsorption of the antisera against GluR6/7 and KA2 with the respective antigenic peptides, before applying to retina sections, resulted in the complete absence of specific staining (Fig. 2B,D).

\section{Subcellular distribution of GluR6/7, KA2, and $\delta 1 / 2$ in the two plexiform layers of the rat retina}

Using pre-embedding immunostaining, the distribution of the iGluR subunits was studied by electron microscopy. As described in Materials and Methods, minimal fixation conditions had to be applied to protect the antigenicity, and therefore the ultrastructural tissue preservation was compromised. Immunoreactivity was found intracellularly because of the epitope specificity of the antisera. It is important to note that an advantage of preembedding immunocytochemistry, compared with postembedding immunocytochemistry, lies with the greater sensitivity because it is not affected by the embedding procedures. However, a disadvantage is that the pre-embedding method does not allow for a quantification of the antibody staining because of the problem of penetration that can lead to false negatives.

\section{Distribution of GluR6/7 and KA2 at photoreceptor synapses in the OPL}

Two horizontal cell processes and one invaginating bipolar cell dendrite are inserted into the photoreceptor ribbon synapses (triads) (Dowling and Boycott, 1966). More than 200 photoreceptor ribbon synapses were studied, and all three members of the triad could be clearly identified in $\sim 40$ cases. In all of these cases it was only one of the two horizontal cell processes labeled for GluR6/7 (Fig. 3). For four synapses this finding was verified by the examination of serial sections. It holds true for both the rod spherules (Fig. 3A,B) and the cone pedicles (Fig. 3C,D) and suggests a heterogeneity of horizontal cells at the molecular level. In none of the 200 photoreceptor synapses examined was GluR6/7 immunoreactivity observed on the dendrites of rod bipolar cells or on the dendrites of flat or invaginating cone bipolar cells.

Staining for the KA2 subunit was also present in the OPL, but the number of KA2-immunoreactive processes was low. Looking at the photoreceptor terminals, in all cases in which KA2immunolabeled processes were found $(\sim 20)$ they were present postsynaptically at cone pedicles and never postsynaptically at rod spherules (Fig. 4). The processes stained for KA2 are most likely dendrites of OFF-cone bipolar cells, because (1) all the stained processes that were found postsynaptically at cone pedicles made flat (basal) contacts with the cone pedicles and never invaginated into the terminals, as known for the dendrites of ON-cone bipolar cells (Dowling and Boycott, 1966), and (2) they were never associated with the cone synaptic complex (Fig. 4). Neither the two lateral elements at the cone synapse, the horizontal cell processes, nor the central invaginating element, the dendrite of an ON-cone bipolar cell, was ever found to be labeled for KA2 (Fig. 4).

\section{Distribution of GluR6/7, KA2, and $\delta 1 / 2$ at bipolar cell synapses in the IPL}

In the IPL, neuronal processes postsynaptic to OFF-cone bipolar cell terminals (Figs. 5A, 6A), ON-cone bipolar cell terminals (Figs. $5 B, 6 B$ ) and rod bipolar cell terminals (Figs. 5C, 6C) were labeled for the kainate receptor subunits GluR6/7 (Fig. 5) and KA2 (Fig. 6). In 70-80\% of the cases in which GluR6/7- and KA2-immunoreactive processes were found, they were present postsynaptically at ribbon synapses of OFF- and ON-cone bipolar cells and only in the remainder postsynaptically at rod bipolar cell ribbon synapses. In all cases, independent of the type of bipolar cell, only one of the two postsynaptic elements at the bipolar cell dyad was stained for GluR6/7 or KA2. Whereas at the rod bipolar cell synapse both postsynaptic elements are amacrine cell processes (Famiglietti and Kolb, 1975; Chun et al., 1993), at the cone bipolar cell synapses the two postsynaptic elements are in most cases a process of an amacrine cell and a dendrite of a ganglion cell (Dowling and Boycott, 1966). Processes of amacrine cells as well as dendrites of ganglion cells were found to be stained for the kainate receptor subunits. This is in agreement with the results from in situ hybridization studies reporting the expression of mRNAs for these GluR subunits in amacrine and ganglion cells (Hamassaki-Britto et al., 1993; Brandstätter et al., 1994).

Staining for the $\delta 1 / 2$ subunits was found in amacrine cell processes postsynaptic to rod bipolar cell terminals (Fig. 7A,B) and most likely in amacrine cell processes as well as ganglion cell processes postsynaptic to OFF-cone (Fig. $7 C$ ) and ON-cone (Fig. 7D) bipolar cells. As with the kainate receptor subunits GluR6/7 and KA2, only one of the two postsynaptic elements at the bipolar cell dyad was stained for the $\delta 1 / 2$ subunits. In a few cases, we were able to identify the labeled postsynaptic process at the rod bipolar cell synapse as belonging to an AII amacrine cell (Fig. 7A). The second amacrine cell at this synapse in Figure $7 A$ is not stained. It makes a reciprocal synapse onto the rod bipolar terminal and is most likely a GABAergic amacrine cell of the A17 type (Kolb and Famiglietti, 1974; Kolb, 1979; Raviola and Dacheux, 1987).

\section{DISCUSSION}

In the present study we report the distribution of kainate receptor subunits at the synapses in the plexiform layers of the rat retina. Whereas GluR6/7 and KA2 were present in both the OPL and the IPL, $\delta 1 / 2$ was found only in the IPL.

The electrophysiological identification of kainate receptors is difficult, because the response of a neuron to kainate is often masked by the activation of AMPA receptors showing high affinity for kainate (for review, see Hollmann and Heinemann, 1994) or because kainate receptors could be restrictedly expressed at only certain parts of a neuron. These impediments could be the reason that kainate responses have only recently been described for neurons in the CNS (Lerma et al., 1993, 1997; Wilding and Huettner, 1997). A detailed knowledge of the distribution of kainate receptors is an important first step toward the understanding of their role in glutamatergic synaptic transmission. 


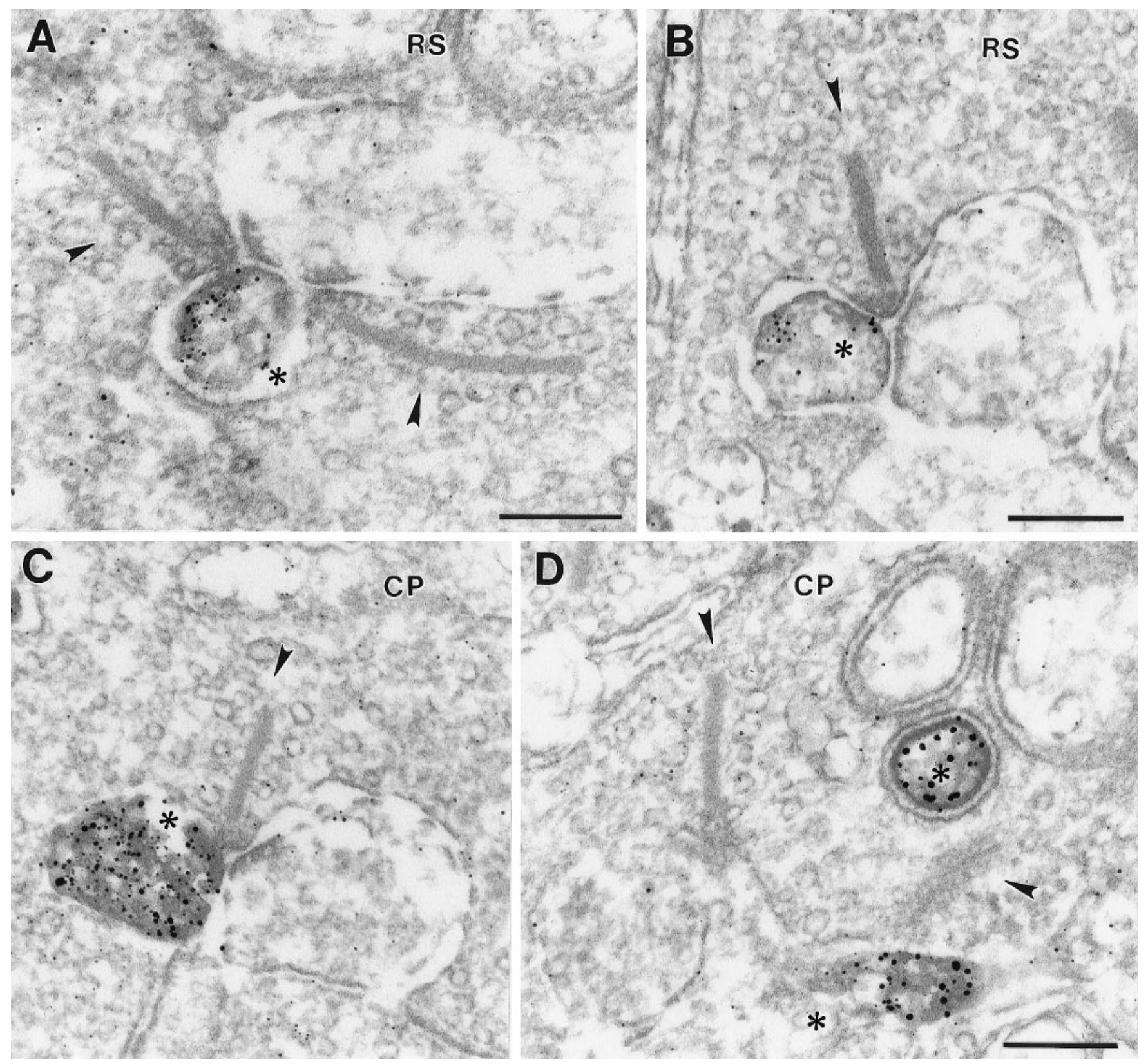

Figure 3. High-power electron micrographs showing the ultrastructural localization of GluR6/7 immunoreactivity in the OPL. $A, B$, GluR6/7 staining in the OPL was found in horizontal cell processes (asterisk) postsynaptic to rod spherules $(R S)$, and $(C, D)$ in horizontal cell processes $($ asterisk) postsynaptic to cone pedicles $(C P)$. Note in each case that only one of the two lateral horizontal cell processes at the photoreceptor synapses is labeled for GluR6/7. The presynaptic ribbon in the terminals of the photoreceptor cells is marked with an arrowhead. Scale bars: $0.2 \mu \mathrm{m}$ (shown in $D$ for $C, D$ ).

\section{Immunocytochemical localization of kainate receptors in the mammalian retina}

So far, there is only one full length paper available showing the distribution of kainate receptors in the rat retina (Peng et al., 1995). Using an antiserum against GluR6/7 and light microscopy, Peng et al. (1995) reported strong labeling of horizontal cells and their processes in the OPL and of some amacrine and ganglion cells and their processes in the IPL of the rat retina. The staining for GluR6/7 was present all along the cell membranes. This is in contrast to the result shown in Figure 1 of this paper, where strong label is found in the plexiform layers and only weak extrasynaptic immunofluorescence was observed. On the basis of our previous studies on the localization of neurotransmitter re- ceptors, we find that strong fixation causes a disappearance of the label in synaptic hot spots and a relative increase of extrasynaptic staining (Grünert and Wässle, 1993; Hartveit et al., 1994; SassoèPognetto et al., 1994; Greferath et al., 1995; Brandstätter et al., 1996; Enz et al., 1996). A similar relationship between immunostaining and the fixation has also been reported for the localization of $\mathrm{GABA}_{\mathrm{A}}$ receptors and NMDA receptors in brain tissue (Weinmann et al., 1997). The retina in the study by Peng et al. (1995) was fixed overnight, and this might explain their strong labeling of cell membranes and the absence of punctate immunofluorescence.

In a study available only as an abstract (Morigiwa et al., 1995), GluR6/7 was investigated in different mammalian retinae. 


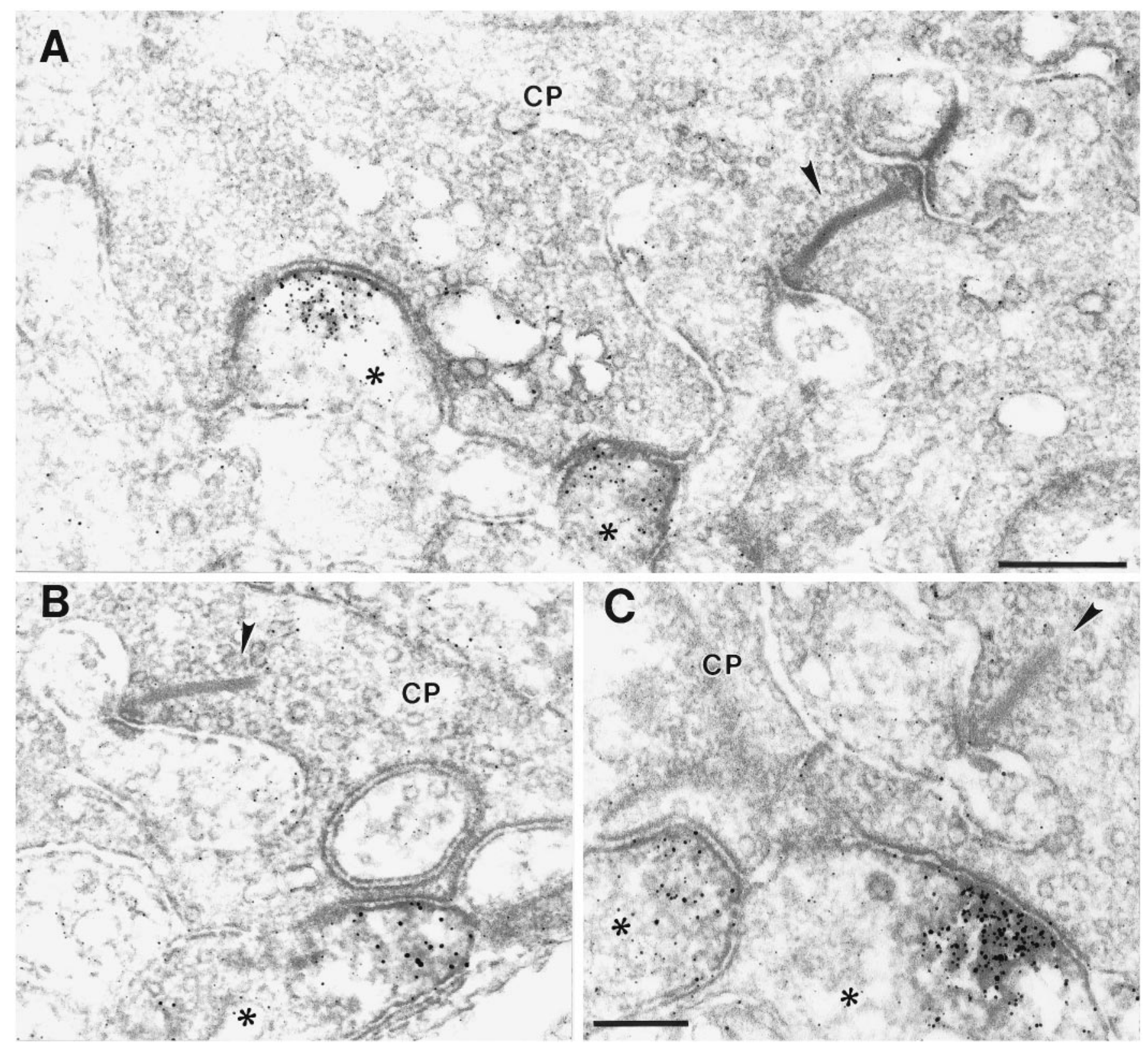

Figure 4. High-power electron micrographs showing the ultrastructural localization of KA2 immunoreactivity in the OPL. $A-C$, KA2 staining in the OPL was found in dendrites of OFF-cone bipolar cells (asterisk) that made flat contacts with the cone pedicles $(C P)$ and were never associated with the synaptic complex of the $C P$. The presynaptic ribbon in the $C P$ s is marked with an arrowhead. Scale bars ( $\operatorname{shown}$ in $A$ for $A, B$ ): $0.3 \mu \mathrm{m} ; C, 0.2 \mu \mathrm{m}$.

GluR6/7 was found in horizontal cells and not in bipolar cells. Strong immunoreactivity was also observed in the IPL.

\section{Selective distribution of GluR6/7 and KA2 at synapses in the OPL}

The present study has shown a selective synaptic distribution of the receptor subunits in both plexiform layers of the retina. This is most obvious from the localization of GluR6/7 and KA2 at the photoreceptor synapses in the OPL.

The processes found to be labeled for the GluR6/7 subunits in the OPL were identified as horizontal cell processes postsynaptic to both rods and cones. The postsynaptic complex at a photoreceptor synapse consists of two lateral elements, the processes of horizontal cells, and a central element, the dendrite of an $\mathrm{ON}$ bipolar cell (Dowling and Boycott, 1966). As a rule, in all the cases where staining of horizontal cell processes was found postsynaptically at photoreceptor terminals, only one of the two horizontal cell processes was labeled for GluR6/7. This selective receptor distribution in rat horizontal cells is unexpected, because it has been shown that, in contrast to other mammalian retinae, which all have two types of horizontal cells, only one type, the axon-bearing B-type horizontal cell, is found in the rat retina (Peichl and González-Soriano, 1993). Therefore, our results suggest a molecular heterogeneity of horizontal cells at the level of expression of neurotransmitter receptors, in addition to the well known morphological heterogeneity of horizontal cells (Ramon y Cajal, 1893; Gallego, 1976; Boycott, 1988). From our results, however, we are not able to say whether this selective expression of the GluR6/7 subunits in the horizontal cell pro- 


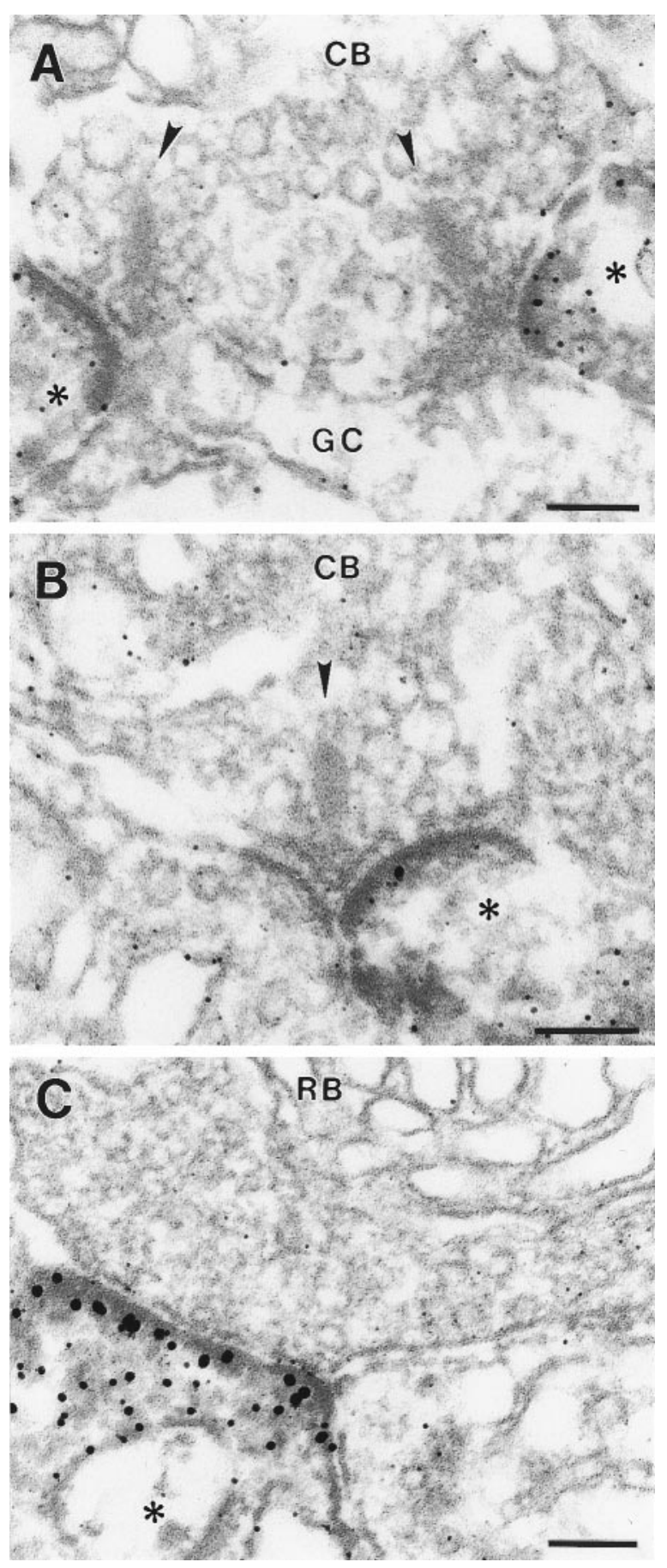

Figure 5. High-power electron micrographs showing the ultrastructural localization of GluR6/7 immunoreactivity at synapses in the IPL. GluR6/7 staining in the IPL was detected in the processes of amacrine and ganglion cells (asterisk) postsynaptic to OFF-cone $(A ; C B)$, ON-cone $(B ; C B)$, and rod bipolar cells $(C ; R B)$. Note in each case that only one of the two postsynaptic elements at the bipolar cell dyad is labeled for GluR6/7. The presynaptic ribbon in the terminals of the bipolar cells in $A$ and $B$ is marked with an arrowhead. GC, Ganglion cell. Scale bars, $0.1 \mu \mathrm{m}$.

cesses at the photoreceptor synapses arises from the differential expression of these subunits by neighboring horizontal cells or from the differential expression of these subunits by one and the same horizontal cell. Qin and Pourcho (1996) used light microscopy to study the distribution of the AMPA receptor subunits GluR1-GluR4 in the cat retina. They found specific expression
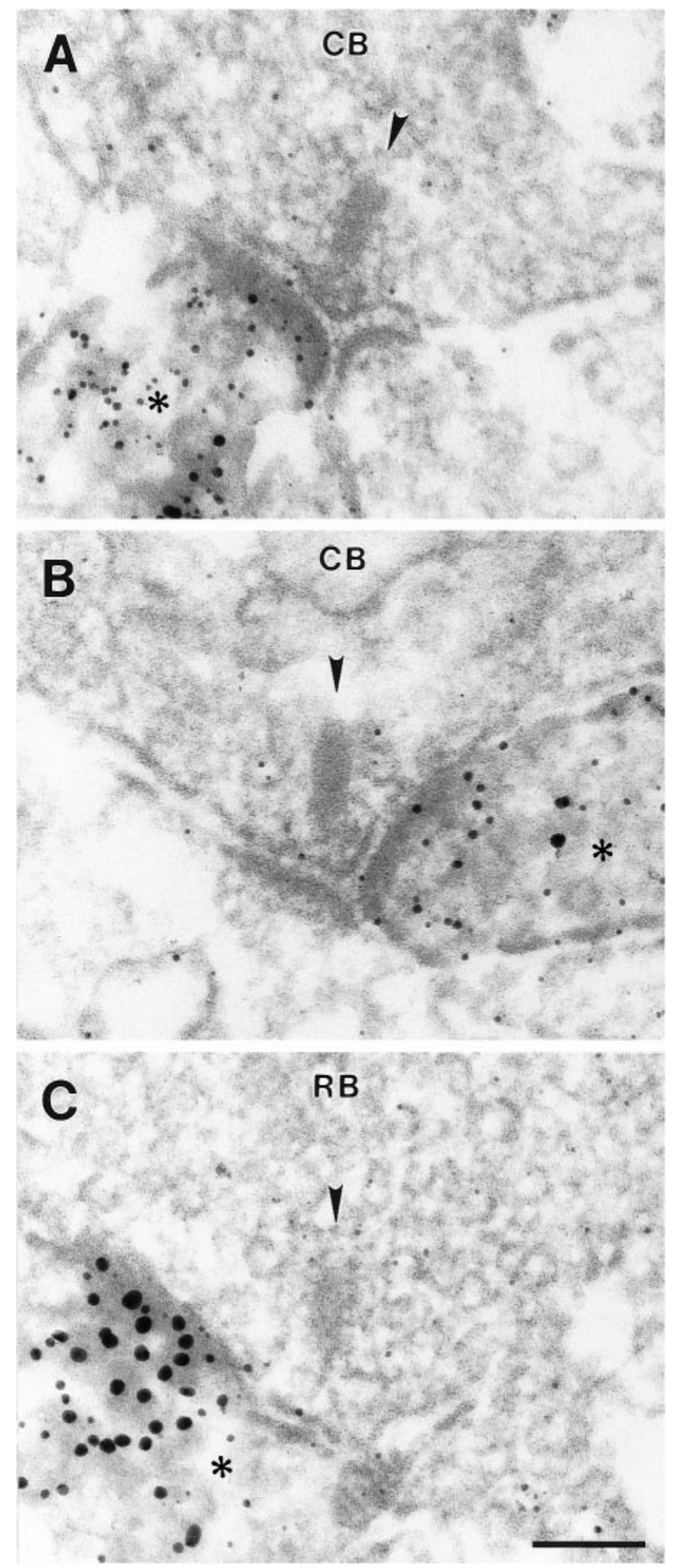

Figure 6. High-power electron micrographs showing the ultrastructural localization of KA2 immunoreactivity at synapses in the IPL. KA2 staining in the IPL was detected in the processes of amacrine and ganglion cells (asterisk) postsynaptic to OFF-cone $(A ; C B)$, ON-cone $(B$; $C B)$, and rod bipolar cells $(C ; R B)$. Note in each case that only one of the two postsynaptic elements at the bipolar cell dyad is labeled for KA2. The presynaptic ribbon in the terminals of the bipolar cells is marked with an arrowhead. Scale bar (shown in $C$ for $A-C$ ): $0.1 \mu \mathrm{m}$.

patterns and described horizontal cells as expressing the different AMPA receptor subunits. These results and the results of the present study indicate that mammalian horizontal cells apparently express different types of iGluRs, and that a horizontal cell could selectively express these receptors at different synapses.

The kainate receptor subunit KA2 was found only postsynaptic 


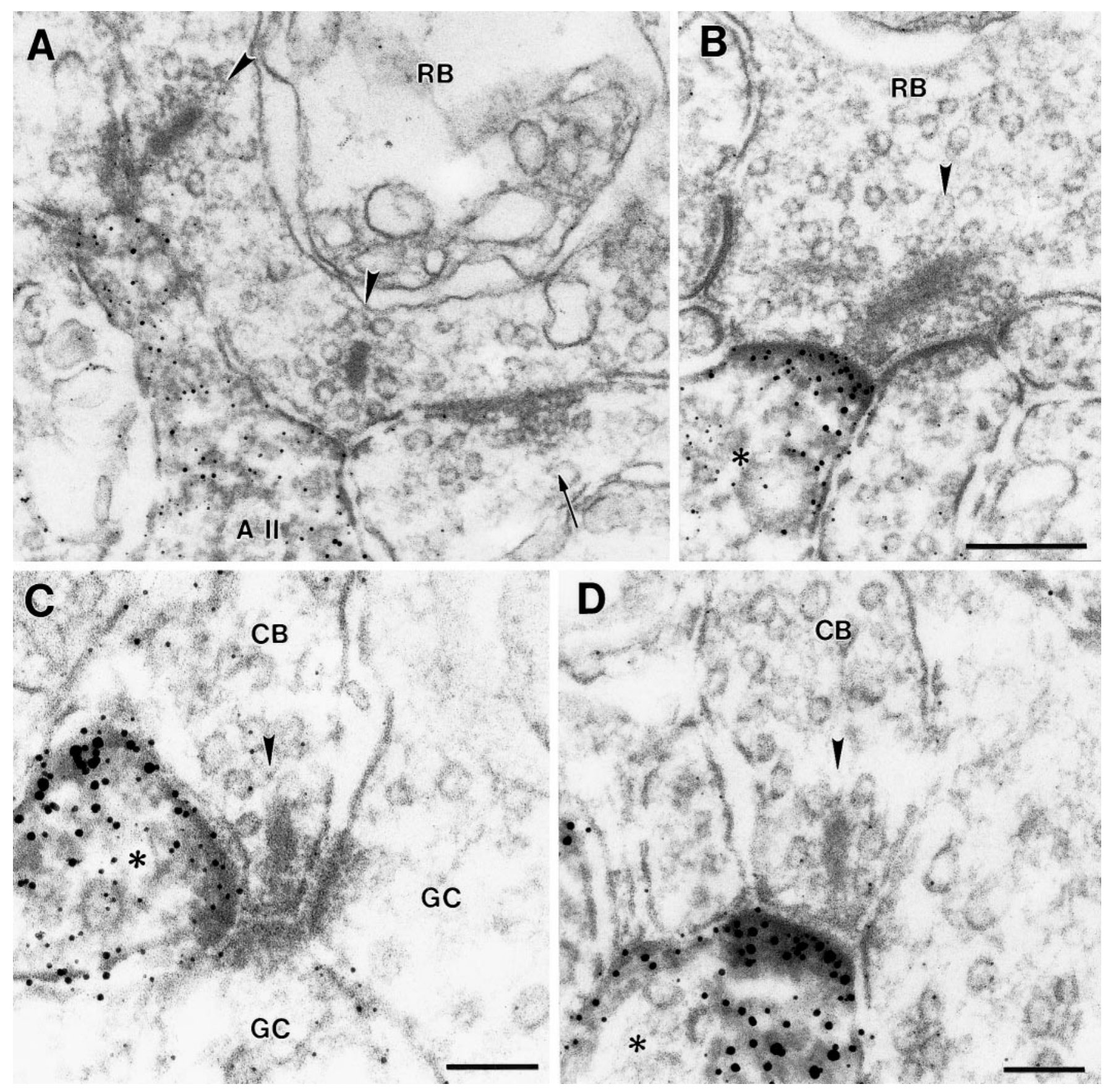

Figure 7. High-power electron micrographs showing the ultrastructural localization of $\delta 1 / 2$ immunoreactivity at synapses in the IPL. $A, B, \delta 1 / 2$ staining was found in amacrine cell processes postsynaptic to rod bipolar cell $(R B)$ ribbon synapses. In $A$, the labeled amacrine cell was identified as an AII amacrine cell. The second amacrine cell at the bipolar dyad in $A$, making a reciprocal synapse onto the bipolar terminal (arrow), is not labeled. In $B$, the labeled amacrine cell process (asterisk) postsynaptic to the rod bipolar cell $(R B)$ synapse could not be identified. $C, D, \delta 1 / 2$ staining was also present in processes of amacrine and ganglion cells (asterisk) postsynaptic to OFF-cone $(C ; C B)$ and ON-cone $(D ; C B)$ bipolar cell synapses. Note at all bipolar cell synapses shown in $A-D$ that only one of the two postsynaptic elements is labeled for $\delta 1 / 2$. GC, Ganglion cell. The presynaptic ribbon in the terminals of the bipolar cells is marked with an arrowhead. Scale bars (shown in $B$ for $A, B$ ): $0.2 \mu \mathrm{m} ; C, D, 0.1 \mu \mathrm{m}$.

to cones in dendrites of OFF bipolar cells. The hypothesis for the creation of the ON/OFF dichotomy in the mammalian retina is that $\mathrm{ON}$ and $\mathrm{OFF}$ bipolar cells use functionally different GluRs at their dendrites. It is known that ON-cone bipolar cells and rod bipolar cells of the mammalian retina express mGluR6 at their dendrites, a mGluR that inverts the hyperpolarizing light response of photoreceptors into a depolarization of the ON bipolar cells (Yamashita and Wässle, 1991; Nomura et al., 1994; de la
Villa et al., 1995; Masu et al., 1995; Euler et al., 1996). In this study, we report the presence of the kainate receptor KA2 in dendrites of OFF bipolar cells. This iGluR could be responsible for the sign-conserving signal transfer at certain photoreceptors to OFF bipolar cell synapses in the OPL.

The result of the differential distribution of the kainate receptor subunits GluR6/7 and KA2 in the OPL demonstrates further that these receptor subunits are not colocalized. This is interest- 
ing because in in vitro studies no electrophysiological responses were detected when KA2 was expressed alone. Coexpression of KA2 together with GluR5 or GluR6, however, can form functional heteromeric receptors (Herb et al., 1992; Sakimura et al., 1992). Because of the lack of a specific antibody against the GluR5 subunit, we were not able to look for a possible coexpression with KA2 in dendrites of OFF bipolar cells. Nevertheless, our results could also suggest that KA2 can function as a homomeric receptor in vivo, in contrast to the in vitro situation.

Finally, the results of studies on the effects of kainic acid on the synaptic organization of the vertebrate retina should be discussed (Yazulla and Kleinschmidt, 1980; Kleinschmidt et al., 1986). It was found that kainic acid had little effect on photoreceptors and certain types of bipolar cells but had a strongly neurotoxic effect on horizontal cells. This would fit with our results showing that photoreceptor cells and ON-cone bipolar cells did not express kainate receptors but that horizontal cells and OFF-cone bipolar cells did. Furthermore, Yazulla and Kleinschmidt (1980) reported for the goldfish retina that only a single horizontal cell process invaginating into the rod spherule was affected by kainic acid neurotoxicity, whereas many processes were found to be affected in a cone pedicle. These findings, again, would fit with our results in the rat retina showing that in rod spherules only one horizontal cell process was labeled for a kainate receptor subunit, whereas in the cone pedicles several elements, horizontal cell processes and OFF-cone bipolar cell dendrites, were labeled for kainate receptor subunits.

In summary, the selective distribution of the kainate receptor subunits GluR6/7 and KA2 at the photoreceptor synapses (this study) and of certain mGluRs (Nomura et al., 1994; Koulen et al., 1997) creates functional heterogeneity in the OPL and suggests specific processing of visual information already at the first synapse in the retina.

\section{Selective distribution of GluR6/7, KA2, and $\delta 1 / 2$ at synapses in the IPL}

As in the OPL, we found the different iGluRs in the IPL to be selectively distributed at bipolar cell ribbon synapses. All the receptor subunits studied were found to be localized postsynaptically to OFF and ON bipolar cell synapses in amacrine and ganglion cell processes. This result is especially interesting for the $\delta 1 / 2$ subunits. As mentioned before, these subunits are structurally related to iGluRs, but they do not belong to the three main classes of iGluRs. Their function is still an open issue, and it has been shown only recently that mice defective in the $\delta 2$ subunit are ataxic and have defects in Purkinje cell synapse formation and cerebellar long-term depression (Kashiwabuchi et al., 1995). The selective distribution of $\delta 1 / 2$ subunits at the different glutamatergic synapses in the IPL, for example, in AII amacrine cells, clearly points to a role for these receptor subunits in glutamatergic synaptic transmission in the retina. In future studies, it will be of interest to determine whether $\delta 1 / 2$ subunits are present at synapses on their own or whether they colocalize with other iGluR subunits to form functional receptor channels. A coexpression of the $\delta 1 / 2$ subunits and the AMPA receptor subunits GluR2/3 has been shown at synapses between parallel fibers and Purkinje cell spines in the rat cerebellum (Sommer Landsend et al., 1997).

The most important result from the distribution analysis of GluR6/7, KA2, and $\delta 1 / 2$ in the IPL was their presence, always, in only one of the two postsynaptic elements at the bipolar cell dyads. This finding has been true for every GluR, ionotropic or metabotropic, that has been studied so far by our group (Hartveit et al., 1994; Brandstätter et al., 1996; Koulen et al., 1996, 1997). This selective synaptic distribution of GluRs could be a key factor in creating the basis for the differential processing of glutamatergic signals in the retina.

\section{REFERENCES}

Araki K, Meguro H, Kushiya E, Takayama C, Inoue Y, Mishina M (1993) Selective expression of the glutamate receptor channel delta 2 subunit in cerebellar Purkinje cells. Biochem Biophys Res Commun 197:1267-1276.

Bettler B, Egebjerg J, Sharma G, Pecht G, Hermans-Borgmeyer I, Moll C, Stevens CF, Heinemann S (1992) Cloning of a putative glutamate receptor: a low affinity kainate-binding subunit. Neuron 8:257-265.

Boycott BB (1988) Horizontal cells of mammalian retinae. Neurosci Res [Suppl] 8:97-111.

Brandstätter JH, Hartveit E, Sassoè-Pognetto M, Wässle H (1994) Expression of NMDA and high-affinity kainate receptor subunit mRNAs in the adult rat retina. Eur J Neurosci 6:1100-1112.

Brandstätter JH, Koulen P, Kuhn R, van der Putten H, Wässle H (1996) Compartmental localization of a metabotropic glutamate receptor (mGluR7): two different active sites at a retinal synapse. J Neurosci 16:4749-4756.

Chun M-H, Han S-H, Chung J-W, Wässle H (1993) Electron microscopic analysis of the rod pathway of the rat retina. J Comp Neurol 332:421-432.

de la Villa P, Kurahashi T, Kaneko A (1995) L-glutamate-induced responses and cGMP-activated channels in three subtypes of retinal bipolar cells dissociated from the cat. J Neurosci 15:3571-3582.

Djamgoz MBA, Wagner HJ, Witkovsky P (1995) Photoreceptorhorizontal cell connectivity, synaptic transmission and neuromodulation. In: Neurobiology and clinical aspects of the outer retina (Djamgoz MBA, Archer SN, Vallerga S, eds), pp 155-193. London: Chapman and Hall.

Dowling JE, Boycott BB (1966) Organization of the primate retina: electron microscopy. Proc R Soc Lond [Biol] 166:80-111.

Egebjerg J, Bettler B, Hermans-Borgmeyer I, Heinemann S (1991) Cloning of a cDNA for a glutamate receptor subunit activated by kainate but not AMPA. Nature 351:745-748.

Enz R, Brandstätter JH, Wässle H, Bormann J (1996) Immunocytochemical localization of the $\mathrm{GABA}_{\mathrm{C}}$ receptor $\rho$ subunits in the mammalian retina. J Neurosci 16:4479-4490.

Euler T, Schneider H, Wässle H (1996) Glutamate responses of bipolar cells in a slice preparation of the rat retina. J Neurosci 16:2934-2944.

Famiglietti EV, Kolb H (1975) A bistratified amacrine cell and synaptic circuitry in the inner plexiform layer of the retina. Brain Res 84:293-300.

Gallego A (1976) Comparative study of the horizontal cells in the vertebrate retina: mammals and birds. In: Neural principles in vision (Zettler F, Weiler R, eds), pp 26-62. Berlin: Springer.

Greferath U, Grünert U, Fritschy JM, Stephenson A, Möhler H, Wässle $\mathrm{H}$ (1995) $\mathrm{GABA}_{\mathrm{A}}$ receptor subunits have differential distribution in the rat retina: in situ hybridization and immunohistochemistry. J Comp Neurol 353:553-571.

Grünert U, Wässle H (1993) Immunocytochemical localization of glycine receptors in the mammalian retina. J Comp Neurol 335:523-537.

Hamassaki-Britto DE, Hermans-Borgmeyer I, Heinemann S, Hughes TE (1993) Expression of glutamate receptor genes in the mammalian retina: the localization of GluR1 through GluR7 mRNAs. J Neurosci 13:1888-1898.

Hartveit E, Brandstätter JH, Sassoè-Pognetto M, Laurie DJ, Seeburg PH, Wässle H (1994) Localization and developmental expression of the NMDA receptor subunit NR2A in the mammalian retina. J Comp Neurol 348:570-582.

Herb A, Burnashev N, Werner P, Sakmann B, Wisden W, Seeburg PH (1992) The KA2 subunit of excitatory amino acid receptors shows widespread expression in brain and forms ion channels with distantly related subunits. Neuron 8:775-785.

Hollmann M, Heinemann S (1994) Cloned glutamate receptors. Annu Rev Neurosci 17:31-108.

Hughes TE (1997) Are there ionotropic glutamate receptors on the rod bipolar cell of the mouse retina? Vis Neurosci 14:103-109.

Hughes TE, Hermans-Borgmeyer I, Heinemann S (1992) Differential expression of glutamate receptor genes (GluR1-5) in the rat retina. Vis Neurosci 8:49-55. 
Kashiwabuchi N, Ikeda K, Araki K, Hirano T, Shibuki K, Takayama C, Inoue Y, Kutsuwada T, Yagi T, Kang Y, Aizawa S, Mishina M (1995) Impairment of motor coordination, Purkinje cell synapse formation, and cerebellar long-term depression in GluR $\delta 2$ mutant mice. Cell 81:245-252.

Kleinschmidt J, Zucker CL, Yazulla S (1986) Neurotoxic action of kainic acid in the isolated toad and goldfish retina: I. Description of effects. J Comp Neurol 254:184-195.

Kolb H (1979) The inner plexiform layer in the retina of the cat: electron microscopic observations. J Neurocytol 8:295-329.

Kolb H, Famiglietti EV (1974) Rod and cone pathways in the inner plexiform layer of cat retina. Science 186:47-49.

Koulen P, Malitschek B, Kuhn R, Wässle H, Brandstätter JH (1996) Group II and group III metabotropic glutamate receptors in the rat retina: distributions and developmental expression patterns. Eur J Neurosci 8:2177-2187.

Koulen P, Kuhn R, Wässle H, Brandstätter JH (1997) Group I metabotropic glutamate receptors mGluR1 $\alpha$ and mGluR5a: localization in both synaptic layers of the rat retina. J Neurosci 17:2200-2211.

Leranth C, Pickel VM (1989) Electron microscopic preembedding double-immunostaining methods. In: Neuroanatomical tract-tracing methods 2. Recent progress (Heimer L, Záborszky L, eds), pp 129-172. New York: Plenum.

Lerma J, Paternain AV, Naranjo JR, Mellström B (1993) Functional kainate-selective glutamate receptors in cultured hippocampal neurons. Proc Natl Acad Sci USA 90:11688-11692.

Lerma J, Morales M, Vicente MA, Herreras O (1997) Glutamate receptors of the kainate type and synaptic transmission. Trends Neurosci 20:9-12.

Lomeli H, Sprengel R, Laurie DJ, Köhr G, Herb A, Seeburg PH, Wisden W (1993) The rat delta-1 and delta-2 subunits extend the excitatory amino acid receptor family. FEBS Lett 315:318-322.

Massey SC (1990) Cell types using glutamate as a neurotransmitter in the vertebrate retina. In: Progress in retinal research (Osborne $\mathrm{N}$, Chader J, eds), pp 399-425. Oxford: Pergamon.

Masu M, Iwakabe H, Tagawa Y, Miyoshi T, Yamashita M, Fukuda Y, Sasaki H, Hiroi K, Nakamura Y, Shigemoto R, Takada M, Nakamura K, Nakao K, Katsuki M, Nakanishi S (1995) Specific deficit of the ON response in visual transmission by targeted disruption of the mGluR6 gene. Cell 80:757-765.

Mayat E, Petralia RS, Wang Y-X, Wenthold RJ (1995) Immunoprecipitation, immunoblotting, and immunocytochemistry studies suggest that glutamate receptor $\delta$ subunits form novel postsynaptic receptor complexes. J Neurosci 15:2533-2546.

Monaghan DT, Bridges RJ, Cotman CW (1989) The excitatory amino acid receptors: their classes, pharmacology, and distinct properties in the function of the central nervous system. Annu Rev Pharmacol Toxicol 29:365-402.

Morigiwa K, Vardi N, Sterling P (1995) Immunostaining for glutamate receptor subunits in mammalian retina. Soc Neurosci Abstr 21[part 2]:901.

Müller F, Greferath U, Wässle H, Wisden W, Seeburg PH (1992) Glutamate receptor expression in the rat retina. Neurosci Lett 138:179-182.

Nakajima Y, Iwakabe H, Akazawa C, Nawa H, Shigemoto R, Mizuno N, Nakanishi S (1993) Molecular characterization of a novel retinal metabotropic glutamate receptor mGluR6 with a high agonist selectivity for L-2-amino-4- phosphonobutyrate. J Biol Chem 268:11868-11873.

Nomura A, Shigemoto R, Nakamura Y, Okamoto N, Mizuno N, Nakanishi S (1994) Developmentally regulated postsynaptic localization of a metabotropic glutamate receptor in rat rod bipolar cells. Cell 77:361-369.

Peichl L, González-Soriano J (1993) Unexpected presence of neurofilaments in axon-bearing horizontal cells of the mammalian retina. J Neurosci 13:4091-4100.

Peng Y-W, Blackstone CD, Huganir RL, Yau KW (1995) Distribution of glutamate receptor subtypes in the vertebrate retina. Neuroscience 66:483-497.

Pin JP, Duvoisin R (1995) Neurotransmitter receptors I. The metabotropic glutamate receptors: structure and functions. Neuropharmacology 34:1-26.

Qin P, Pourcho RG (1996) Distribution of AMPA-selective glutamate receptor subunits in cat retina. Brain Res 710:303-307.

Ramon y Cajal S (1893) La rétine des vertébrés. La Cellule 9:119-257.

Raviola E, Dacheux RF (1987) Excitatory dyad synapse in rabbit retina. Proc Natl Acad Sci USA 84:7324-7328.

Sakimura K, Morita T, Kushiya E, Mishina M (1992) Primary structure and expression of the $\gamma 2$ subunit of the glutamate receptor channel selective for kainate. Neuron 8:267-274.

Sassoè-Pognetto M, Wässle H, Grünert U (1994) Glycinergic synapses in the rod pathway of the rat retina: cone bipolar cells express the $\alpha 1$ subunit of the glycine receptor. J Neurosci 14:5131-5146.

Seeburg PH (1993) The molecular biology of mammalian glutamate receptor channels. Trends Neurosci 16:359-365.

Shiells R (1995) Photoreceptor-bipolar cell transmission. In: Neurobiology and clinical aspects of the outer retina (Djamgoz MBA, Archer SN, Vallerga S, eds), pp 297-324. London: Chapman and Hall.

Sommer Landsend A, Amiry-Moghaddam M, Matsubara A, Bergersen L, Usami S, Wenthold RJ, Ottersen OP (1997) Differential localization of $\delta$ glutamate receptors in the rat cerebellum: coexpression with AMPA receptors in parallel fiber-spine synapses and absence from climbing fiber-spine synapses. J Neurosci 17:834-842.

Weinmann O, Loup F, Fritschy JM (1997) "Unmasking" synaptic NMDA- and $\mathrm{GABA}_{\mathrm{A}}$ receptor subunits by microwave irradiation in rat and human brain tissue. In: Proceedings of the 25th Göttingen Neurobiology Conference (Elsner N, Wässle H, eds), p 827. Stuttgart-New York: Thieme.

Wilding TJ, Huettner JE (1997) Activation and desensitization of hippocampal kainate receptors. J Neurosci 17:2713-2721.

Yamashita M, Wässle H (1991) Responses of rod bipolar cells isolated from rat retina to the glutamate agonist 2-amino-4-phosphonobutyric acid (APB). J Neurosci 11:2372-2382.

Yamazaki M, Araki K, Shibata A, Mishina M (1992) Molecular cloning of a cDNA encoding a novel member of the mouse glutamate receptor channel family. Biochem Biophys Res Commun 183:886-892.

Yazulla S, Kleinschmidt J (1980) The effects of intraocular injection of kainic acid on the synaptic organization of the goldfish retina. Brain Res 182:287-301.

Zhang C, Hammassaki-Britto DE, Britto LRG, Duvoisin RM (1996) Expression of glutamate receptor subunit genes during development of the mouse retina. NeuroReport 8:335-340. 